\title{
An alternative planning paradigm for coastal landscapes and tourism: spatial metrics as indicators for planning coastal tourism landscapes
}

\section{Um paradigma alternativo para o ordenamento do território e o turismo em paisagens costeiras: as métricas espaciais como indicadores para ordenamento e o turismo em paisagens costeiras}

\author{
André Botequilha-Leitão \\ University of Algarve, Faculty of Sciences and Technology and Study Centre for Heritage, Landscape, and Construction (CEPAC), \\ Portugal, aleitao@ualg.pt
}

Emilio Diáz-Varela

University of Santiago de Compostela, Escola Politécnica Superior Lugo, Spain, emilio.diaz@usc.es

\begin{abstract}
Coastal urbanization dynamics in the Algarve are intimately related with tourism, which dominates the regional economy. We present part of the results of a research project in the coastal landscapes of Algarve, focusing on land use and land change, particularly urban sprawl around Faro, one of the highest concentrations of tourism resorts in the region.

We performed a diachronic analysis (1990-2000) based on Corine Land Cover data. We combined contingence tables and landscape metrics. A parsimonious suite of these spatial metrics were selected in order to be easily combined as to derive results with a straightforward interpretation, and moving windows technique facilitated the task in identifying gradients of landscape heterogeneity.
\end{abstract}

Land use planning must pay more attention to tourism, adopting combined spatial approaches, monitor initiatives, and do better plans. Metrics are good indicators for this purpose.

Keywords: Sustainable tourism, Mediterranean coastal landscape, land use change, urban sprawl, spatial metrics.

\section{Introduction}

Coastal urbanization dynamics in the Algarve are intimately related with tourism, the main economic activity by far in the region (CCDR Algarve 2007; Petrov, Lavalle \& Kasanko 2009; Vaz, Nijkamp, Paínho, \& Caetano 2012). In this article we present part of the results of a research project on landscape changes in the region of Algarve, south of Portugal developed at the University of Algarve between 2009 and 2013. Here we focus in a coastal landscape around Faro, the region's capital "Faro-Loulé-Olhão-São Braz de Alportel" (FLOS), particularly on urban sprawl (Botequilha-Leitão \& Diáz Varela, 2009). Its results focused on the period between 1985 and 2000, based on Corine Landcover (CLC) datasets (EEA 2007). In a second phase the project was expanded to the entire region, and included CLC 2006 and COS 1990 and 2007 (Portuguese land use and land cover maps at 1:25.000) (Aguilera \& Botequilha-Leitão, 2012; Aguilera, Botequilha-Leitão \& Diáz-Varela, 2014). Hereby we present unpublished research on the application of landscape metrics to identify trends and impacts in the FLOS coastal landscape. In a subsequent phase of the project a more detailed research on urban dynamics and its relationships with tourism

\section{Resumo}

As dinâmicas urbanas no litoral do Algarve estão intimamente ligadas ao turismo, que domina a economia regional. Apresentamos uma parte dos resultados de um projecto de investigação sobre as alterações do uso do solo nas paisagens costeiras do Algarve, nomeadamente na dispersão urbana em volta de Faro, uma das zonas com maior concentração de "resorts" na região.

Desenvolvemos uma análise diacrónica (1990-2000) baseada no Corine Land Cover combinando tabelas de contingência com métricas da paisagem. Foi seleccionado um conjunto parcimonioso de métricas facilitando o seu uso conjunto e gerando resultados que fossem claramente interpretados; a ténica "janelas móveis" facilitou a identificação de gradientes de heterogeneidade da paisagem.

O ordenamento do território deve prestar mais atenção ao turismo, adoptando abordagens espaciais, monitorizando iniciativas, planeando melhor. As métricas constituem bons indicadores para este fim.

Palavras-chave: Turismo sustentável, paisagens mediterrânicas costeiras, alterações do uso do solo, dispersão urbana, métricas espaciais. is being held, completing it with CLC 2012, recently released in Portugal, and with COS cartography at a more detailed scale.

\subsection{Landscapes and tourism}

High quality landscapes are perceived as exceptional values for the sustainable development of the Mediterranean region (Botequilha-Leitão \& Diáz Varela, 2009) and by force majeure for tourism (Izzo 2010). Landscapes are important not only for the regional cultural identity and its collective memory, for its ecological dimension, for the quality of life they provide to people and communities, but also as key factor for competitiveness of urban, rural and natural areas when compared with other regions, based on the attractiveness and distinctiveness of landscapes. Therefore, landscapes are perceived as territorial capital in order to attract economic development, such as tourism (Hildenbrand, 2008). For example, Brown (2006) argues that tourism preferences are most closely associated with three factors, one being scenic landscape values. According to Rutty and Scott (2016) "coastal tourism is the largest segment of global leisure tourism and it is firmly linked to the destination's natural resources". 
Tourism is important worldwide as an economic activity namely for the European Union (Izzo 2010). For the Algarve it is paramount (Petrov et al., 2009; Vaz et al., 2012). As in most Mediterranean regions, tourism concentrates in the coastal area - the traditional "sun and beach" product that evolved to the present major tourist product "sun and beach + golf". Algarve is under high pressures due to both tourism infrastructures and occupation of coastal resources. The Algarve tourism faces new challenges as entering into a rejuvenation phase (Butler 2011; Almeida, Ferreira \& Costa 2011). Its "sun-sea + golf" base model has to change to enable the Algarve to solve long-term planning issues long due since the last 30 years, namely the seasonality of the main activity and the concentration on the coast. The regional plan PROTAL (CCDR Algarve 2007) proposes incentives for alternative tourist products. Several of these are intimately linked with landscape and environmental quality, such as sustainable tourism.

According to Dodds \& Butler (2010, p. 36)" the evaluation of tourism policy is rare and recommendations to change or augment systems to make policies actually work and be more accountable are even rarer". These authors state that "very few tourism destinations have established policies aimed at preventing overuse or overdevelopment" (Dodds \& Butler 2010, p. 37). Tourism must be further integrated into regional and municipal planning instruments and modus faciendi.

To enable to evaluate land use and sustainable tourism policies and its implementation landscape impacts must be accounted for (White, McCrum, Blackstock \& Scott 2006), and appropriate spatially-explicit indicators are needed. Spatial metrics can serve this purpose as indicators to support planning for sustainable tourism as proposed by Gkoltsiou \& Terkenli (2012).

\subsection{Urban sprawl}

Urbanization is a worldwide phenomenon, arguably the most dramatic form of irreversible land transformation (Seto \& Fragkias 2005; Taubenbock, Wegmann, Roth, Mehl \& Dech 2009). Urban sprawl is a type of urban growth characterized by a low-density, dispersed spatial pattern with both environmental and social impacts (Poelmans \& Van Rompaey 2009).

Based on CLC 2000 data the European Environmental Agency reported an average occupation of $4.8 \%$ for built-up land in Europe (Poelmans \& Van Rompaey 2009). Based also on CLC 2000 built-up land in Portugal occupied $2.7 \%$ (1.9\% in 1985), where discontinuous urban areas represent $70 \%$ of this total (Caetano, Carrão \& Painho 2005).

Portugal experienced strong urbanization between 1985 and 2000 , with urban fabric alone expanding by $31 \%$ (Caetano et al. 2005). This process is particularly expressive on the Portuguese coastal areas: $50 \%$ of the artificial surfaces are located within $15 \mathrm{~km}$ of the ocean which accounts for c. $13 \%$ of Continental Portugal (Freire \& Caetano 2005). Aguilera et al (2014) found for the Central Algarve an urbanization gradient as an exponential curve, extending from the shoreline to $22 \mathrm{~km}$ into the inland. The first $2 \mathrm{~km}$ are characterised by high residential occupation, reaching as much as $20 \%$ of the total area of this sector.

In the last two decades the Algarve region's population evolved from 341.075 inhabitants (1991) to 383.399 (2000) (+12.4\%) to 450.484 (2011) (+17.5\%) (INE 2011). Not surprisingly the population trend observed in the 80 's continued, i.e. concentrate on the coast and desertification of the interior (CCDR Algarve 2004, Map 3 and 5, p. 11 and 16), which is consistent for the country as a whole. The regional coast/interior asymmetries registered for the entire region had a particular emphasis in the coastal landscape system FaroOlhão (CCR Algarve 2002, p. 43).

In the beginning urban sprawl affected mostly the coast ("Litoral" - Figure 1). From the 80's onward it begun "spilling" into the interior, to the "Barrocal", and the study area was no exception, although not so severely as in other municipalities, e.g. Silves or Tavira (CCR Algarve 2002, p. 48).

Figure 1 - Regional landscape units for the region of Algarve. The dark red circle represents roughly the study area location (see also Figure 2). Altitude is represented from blue-green in the lower plains down south to dark red in the small mountains to the North

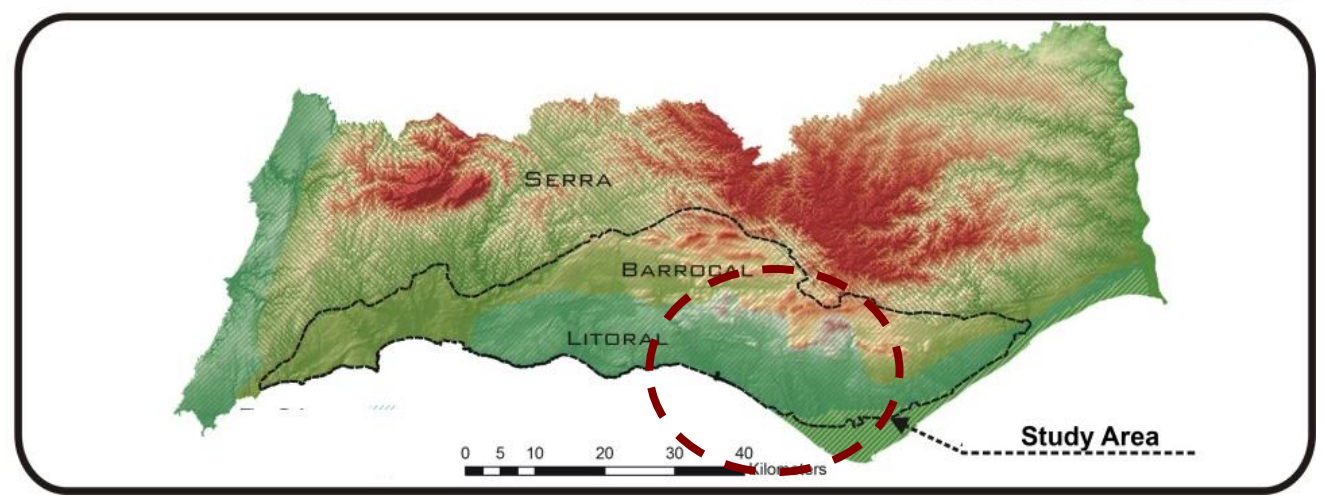


Regarding the study area, since it roughly coincides with the municipality of Faro, its demographics serve as a proxy: 1991 50.000 inhabitants; 2001 - c. 58.000 (CCDR Algarve 2004, Table 2, p.7); 2011 - 64.560 (INE 2011). Faro was the second most populated municipality in the Algarve both in 2001 and 2011, the first being Loulé (INE 2011), one of the other 3 municipalities included in our study (see section 2.1).

\subsection{Research hypothesis and objectives}

We argue that a spatial planning approach for tourism in the Algarve can only be sustainable if closely associated with the maintenance and promotion of the quality of its landscapes. Therefore, it should aim at preventing a dispersed settlement pattern frequently associated with urban sprawl and the subsequent negative impacts or costs. In this context we argue for a closer consideration of tourism and land use planning and the use of landscape metrics as indicators for landscape quality. We aim to characterize land use and land cover (LULC) in the study area between 1985 and 2000 based on CLC data, identify its major trends, and discuss the future role of the coastal landscape of Faro-Loulé-Olhão-São Bras de Alportel for alternative tourism development.

The research hypotheses are that 1 ) due to the geographical coast-inland urban gradient (Aguilera et al., 2014), we hypothesized to find a different structural behavior among areas located in the interior and coastal areas that reflect the decreasing value of costal landscapes due to urban-touristic pressure; 2) landscape metrics (LM) are suitable to capture landscape structural changes and infer potential landscape effects due to urban development induced mainly by tourism; 3) LM can support better planning for tourism in coastal landscapes by allowing spatially-explicit analyses and use these as indicators for monitoring the quality of coastal tourism landscapes; 4) a new paradigm for tourism in the Algarve could be induced by a change on the perception of decision-makers, tourism players and the population at large on the value of semi-natural areas and rural areas with low dynamics of inland landscapes, contributing at the same time to attract economic activities, employment and population and relieving pressure on coastal landscapes.

\section{Methods}

\subsection{Study Area}

The study area is located in the Central Algarve (Figures 1 and 2). This region has experienced significant demographic and land use change in recent decades (Aguilera \& BotequilhaLeitão, 2012; Botequilha- Leitão \& Diáz-Varela, 2009; INE, 2011; Vaz et al., 2012). This is mainly due to tourism, the most important and largely predominant economic activity (Petrov et al., 2009; Vaz et al., 2012). More than 70\% of the Algarve's population lives in the Litoral (Fig. 1), mainly in the region's western-central part -the "Barlavento" (CCDR, 2007). It contains some large agricultural areas, together with almost all the urban areas, including resorts. However, increasing urban pressure is extending from the "Litoral" (Faro, Olhão) towards the "Barrocal" (Loulé, São Braz de Alportel).

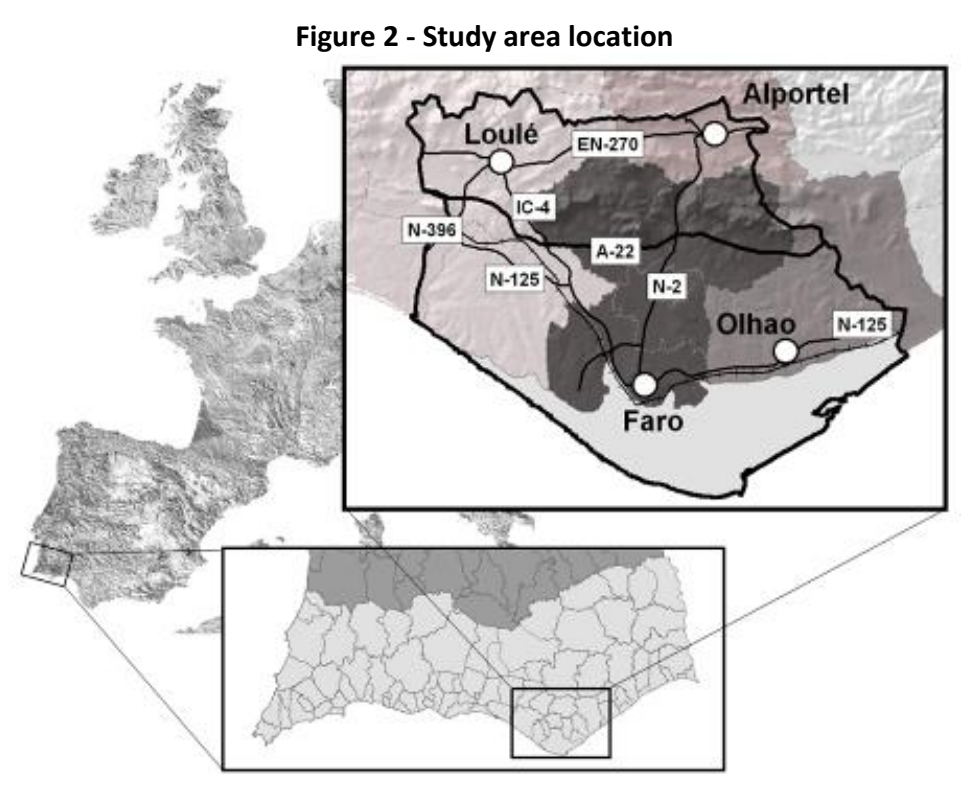

The study area is broadly defined by a polygon formed by the cities of Faro, Olhão, Loulé, and São Brás de Alportel. Along the shoreline two major resorts are closely situated to the west. The town of Olhão to the east has shown recently a growing attraction for tourism. It also includes two urban areas located close but on the inland (Loulé and São Brás de Alportel), and sprawl along major transportation infra-structures. The hinterland between these 4 urban centers is predominantly rural, crossed by transport infrastructures such as highways (A22, IC4), national roads (EN125, N396, and N2), local roads (R270) and railroad infrastructures (Figures 2 and 3). 
Figure 3 - Corine Land Cover data sets for the study area (1990 and 2000).
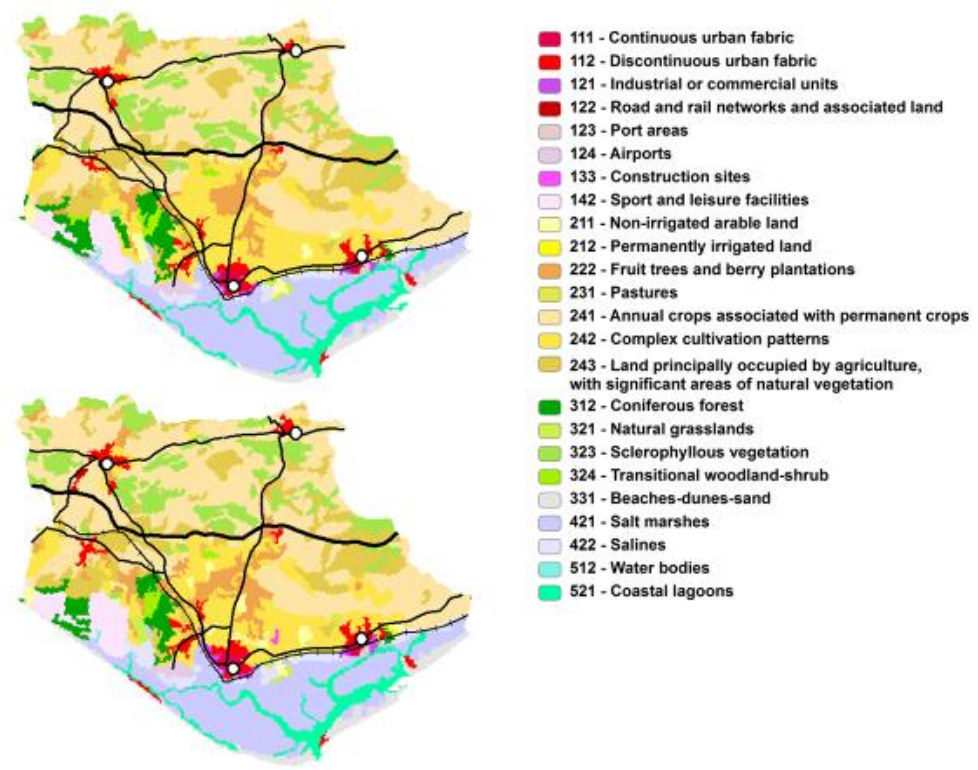

\subsection{Data processing and modeling}

\subsubsection{Digital cartography}

Basins limits forming the study area were defined processing a Digital Elevation Model (DEM) with $100 \mathrm{~m}$ of cell resolution (EROSC, 2007) using the Geographic Information System (GIS) ArcGIS v.9.2. Digital cartography from CORINE (Coordination of Information on the Environment) Land Cover (CLC) Project (EEA, 2007) was used to map land cover. Despite its coarseness, we believe that the use of European level, highly available spatial data would ease the replication of the methodology, and allow comparability between these results and other works developed at national level using CLC data (Caetano et al., 2005; Freire \& Caetano, 2005) as in other countries. Raster datasets with $100 \mathrm{~m}$ of cell resolution, 25 ha of Minimum Mapping Unit (MMU), from years 1990 and 2000 were used. We used the legend third level (maximum disaggregation of data), resulting in a total of 22 land cover classes for 1990, and 25 in 2000 (Figure 4). Linear infrastructures (roads and railroads) and settlements, and the DEM were used to support the analysis.

Figure 4 - Left, spatial distribution of heterogeneity as shown by SHDI. Darker areas represent higher homogeneity. White line represents mean value, while each change in color represents one standard deviation unit. Right, final distribution of homogeneous $(\mathrm{h})$ and heterogeneous areas $(\mathrm{H})$ on the CLC map.

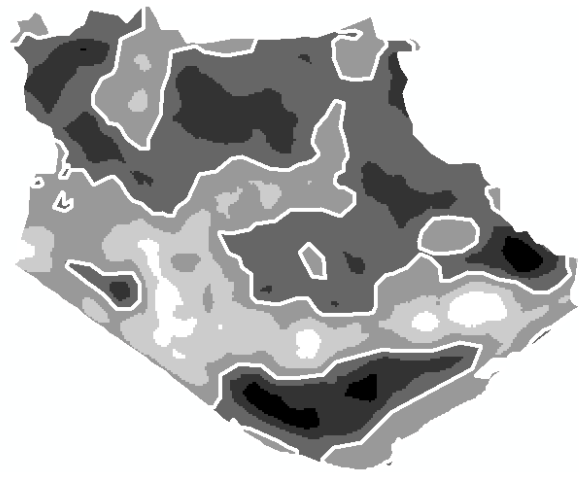

2.2.2 Local character description of Corine Land Cover classes

Once the land cover cartography was obtained, we combined high-resolution remote-sensed data with field work for each land cover type (LCT) in order to check its internal composition and the degree of homogeneity. We compared the land cover map with a QuickBird sensor image (acquisition date December 31, 2004) data available in Google Earth software. Those places where land use was unclear or need clarification were visited on the field. From the 24 LCT considered (Figure 4), we've found

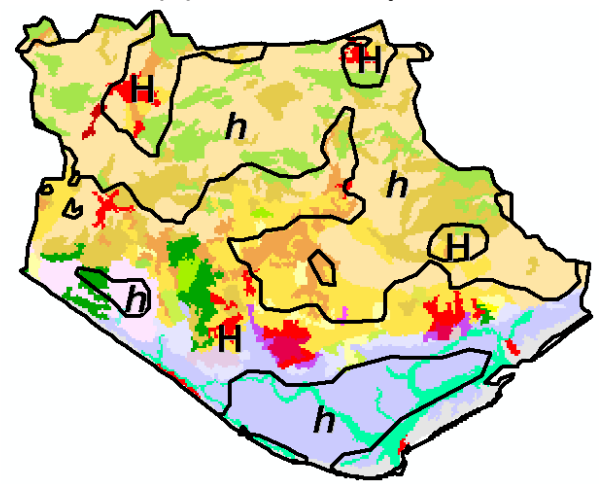

at least six which need to be clarified, as its CLC denomination can be misleading. These are:

- 142-Sport and leisure facilities. Golf courses combined with residential building lots. This corresponds with a strategy of urbanization common in the area, with a very dynamic growth. The land cover also includes little parks and gardens (142-GOLF).

- 211-Non-irrigated arable land. Glasshouses or cultivation under plastic (211-NON-IRRIGATE). 
- 222-Fruit trees and berry plantations. Intensive citrus fruit orchards (222-CITRUS).

- 241- Annual crops associated with permanent crops. Traditional non-irrigated Mediterranean orchards (olives, figs, carobs and amend trees) (241-TRAD ORCHARDS).

- 242- Complex cultivation patterns. Mosaic of land uses, interspersed, with very different degree of intensification: glasshouses and citrus fruit orchards, and abandoned fields with ruderal vegetation, umbrella pines, buildings, etc. (242COMPLEX MOSAIC).

- 243- Land principally occupied by agriculture with significant areas of natural vegetation. Dominated by Mediterranean shrubs (garrigue), occurring also grassland and semi-abandoned pastureland (243- AGRIC SIGN NAT VEGETATION).

\subsubsection{Metrics calculation and analysis}

Landscape metrics can be defined as quantitative indices describing structures or patterns of landscapes (O'Neill et al., 1988), analyzing the composition, spatial context and geometric characteristics of landscape patches, which determine their ecological functions (Forman, 1995). The use of landscape metrics has numerous examples in different fields (e.g. O'Neill et al., 1988; Forman, 1995; Gustafson, 1998; Botequilha \& Ahern, 2002; Botequillha Leitão, Miller, Ahern, \& McGarigal, 2006).

In the last decade or so these metrics have been growingly used to quantify, measure, and evaluate urban landscapes or environments per se (Luck \& Wu, 2002; Herold, Goldstein \& Clarke 2003; Herold, Couclelis \& Clarke, 2005; Seto \& Fragkias, 2005). Many landscape spatial characteristics and phenomena that can be assessed from an ecological perspective, e.g. shape, compaction, diversity, fragmentation, dispersion or aggregation are of increasing interest in the study of the spatial characteristics of urban growth processes, e.g. in both Portuguese (i.e. in Lisbon - Botequilha-Leitão, 2001) and Spanish metropolitan areas (i.e. in Granada - Aguilera et al., 2011 and in Sevilla - Ramos, 2010). Indeed, these indices are being used to determine the spatial statistics of urban areas, being referred as spatial metrics (Herold et al. 2003, 2005; Seto \& Fragkias, 2005; DiBari, 2007). According to the former authors, most research on the monitoring and evaluation of urban change is based on land use statistics, and not on spatial characteristics, as captured by spatial metrics.

\section{Analysis}

We analyzed land use dynamics comparing the evolution of land uses between 1990 and 2000 in a contingence table (CT), combined with the computation of landscape metrics (LM). The $\mathrm{CT}$ is expected to provide quantitative information about changes between LCT, and identify directions of change. It is normally used to analyze the relationship between two variables, and consequently can be applied to compare the evolution of land use and land cover between two years (CalvoIglesias, Fra-Paleo, Crecente-Maseda \& Díaz-Varela, 2006).

The metric's selection was based on their capacity to reflect, in combination with each other, the dynamics of land use evolution and process of transformation in the area for the considered period. The spatial processes responsible for land transformations were summarized by Forman (1995) in five basic types: Perforation (introduction of a new land type into other); dissection (subdividing a land type by a linear structure); fragmentation (breaking up of land type into smaller parts); shrinkage (decrease in size of patches); and attrition (disappearance of patches). These types can be associated with characteristic behavior of certain LM (Botequilha-Leitão \& Ahern, 2002; Botequilha-Leitão et al., 2006).

These authors proposed a core set of metrics for its application to planning. The metrics selected from this core set were: Percentage of Landscape (PLAND), Number of Patches (NP), Mean Patch Area (AREA_MN), Contagion (CONTAG), Mean Radius of Gyration (GYRATE_MN), and Shannon's Diversity Index (SHDI). Metrics computation was performed using the software FRAGSTATS (McGarigal et al., 2002). Mathematical expression and further explanations for each index can be found in the software's webpage (McGarigal et al., 2002) or in Aguilera et al. (2014). Its application to planning is further discussed in Botequilha-Leitão et al. (2006). PLAND, NP, AREA_MN, GYRATE_MN were calculated at the class level. AREA_MN, NP, GYRATE_MN, CONTAG and SHDI were calculated at the landscape level. Note that metrics can be calculated at three levels, depending on the aggregation of data. At patch level metrics are calculated for each separate patch in the landscape (i.e., one result for each patch and metric); at class level the index is calculated and summarized for all patches of each LCT in the landscape (i.e. one result for each LCT and metric); at landscape level metrics are calculated and summarized for the whole landscape (all patches of all LCT), resulting in one result for each metric. Not all metrics can be calculated for all levels, e.g. CONTAG and SHDI can only be computed at landscape level.

\section{Spatial scope for the application of metrics}

Two spatial domains were considered for the application of metrics: (1) study area as a whole; (2) the study area divided according to its heterogeneity. As abovementioned we hypothesized to find a different structural behavior among areas located in the interior and coastal areas. To this end, SHDI was calculated using the moving window option of FRAGSTATS. Moving windows are used for the analysis of landscape pattern with different purposes (Riitters, O'Neill \& Jones, 1997; Roshier, Robertson, Kingsford \& Green, 2001; Pham \& Nakagoshi 2007), including the identification of different heterogeneity areas (Diaz-Varela, Álvarez-López \& Marey-Pérez, 2009).

We performed the analysis on the CLC 2000, trying several windows of growing size until a window completely covered whatever patch on the map (radius of c. 1500m), thus obtaining 
SHDI values above from zero. The resulting map was simplified into two classes ("homogeneous" and "heterogeneous"), reclassifying the values respectively above and under the mean value for the whole map. We obtained a divided map as shown in figure 4. Land cover maps were then intersected with this heterogeneity division, assuming that the intersection with 1990 map wouldn't reflect exactly its heterogeneity distribution, but preferring to establish a fixed temporal reference. Landscape metrics were then calculated separately for each heterogeneity area.

In addition to the straightforward interpretation of the results of the metrics, we selected for each spatial domain (study area, homogeneous zones and heterogeneous zones) the classes with higher PLAND values which altogether sum up to $80 \%$, as a way to detect the most extensive land cover classes, and to identify which classes are contributing more to homogeneity or heterogeneity in the landscape.

\section{Results}

\subsection{More significant changes in land use and land cover related} with urban and tourism development

Changes in the contingency table (Table 1) allow detecting the direction of land cover change by identifying which cover types are substituted by others between 1990 and 2000. Note class "112-DISC URBAN" grew (10.02\%) over "241-TRAD ORCHARDS", due to the expansion of the cities of Loule and São Brás de Alportel (see discussion). This class also grew $7.87 \%$ over "242-COMPLEX MOSAIC", due to periurban development around Faro and Olhão. This last class was also the base for the development of "121-IND COM" (39.55\%) around Loulé, among others, and "142- GOLF" (6.22\%) along the coast west of Faro. The latter also "robbed" $17.25 \%$ of "312-CONIF" which represent large maritime and umbrella pinewoods included in the regional ecological network (ERPVA - CCDR Algarve 2007).

Table 1 - Contingency table: the left diagonal (bold) represent percentage (\%) of change between 1990 and 2000

\begin{tabular}{|c|c|c|c|c|c|c|c|c|c|c|c|c|c|c|c|c|c|c|c|c|c|c|c|c|c|c|}
\hline \multicolumn{27}{|c|}{ CORINE LAND COVER 2000} \\
\hline & & 111 & 112 & 121 & 122 & 123 & 124 & 133 & 142 & 211 & 212 & 222 & 231 & 241 & 242 & 243 & 312 & 321 & 323 & 324 & 331 & 421 & 422 & 512 & 521 & 995 \\
\hline \multirow{26}{*}{ 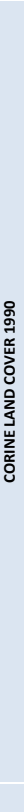 } & 111 & 100,00 & 0,00 & 0,00 & 0,00 & 0,00 & 0,00 & 0,00 & 0,00 & 0,00 & 0,00 & 0,00 & 0,00 & 0,00 & 0,00 & 0,00 & 0,00 & 0,00 & 0,00 & 0,00 & 0,00 & 0,00 & 0,00 & 0,00 & 0,00 & 0,00 \\
\hline & 112 & 0,00 & 81,16 & 0,00 & 0,00 & 0,00 & 0,00 & 0,00 & 0,00 & 0,00 & 0,00 & 0,00 & 0,00 & 0,00 & 0,00 & 0,00 & 0,00 & 0,00 & 0,00 & 0,00 & 0,00 & 0,00 & 0,00 & 0,00 & 0,00 & 0,00 \\
\hline & 121 & 0,00 & 0,00 & 60,45 & 0,00 & 0,00 & 0,00 & 0,00 & 0,00 & 0,00 & 0,00 & 0,00 & 0,00 & 0,00 & 0,00 & 0,00 & 0,00 & 0,00 & 0,00 & 0,00 & 0,00 & 0,00 & 0,00 & 0,00 & 0,00 & 0,00 \\
\hline & 122 & 0,00 & 0,00 & 0,00 & 0,00 & 0,00 & 0,00 & 0,00 & 0,00 & 0,00 & 0,00 & 0,00 & 0,00 & 0,00 & 0,00 & 0,00 & 0,00 & 0,00 & 0,00 & 0,00 & 0,00 & 0,00 & 0,00 & 0,00 & 0,00 & 0,00 \\
\hline & 123 & 0,00 & 0,00 & 0,00 & 0,00 & 100,00 & 0,00 & 0,00 & 0,00 & 0,00 & 0,00 & 0,00 & 0,00 & 0,00 & 0,00 & 0,00 & 0,00 & 0,00 & 0,00 & 0,00 & 0,00 & 0,00 & 0,00 & 0,00 & 0,00 & 0,00 \\
\hline & 124 & 0,00 & 0,00 & 0,00 & 0,00 & 0,00 & 96,53 & 0,00 & 0,00 & 0,00 & 0,00 & 0,00 & 0,00 & 0,00 & 0,00 & 0,00 & 0,00 & 0,00 & 0,00 & 0,00 & 0,00 & 0,00 & 0,00 & 0,00 & 0,00 & 0,00 \\
\hline & 133 & 0,00 & 0,00 & 0,00 & 0,00 & 0,00 & 0,00 & 0,00 & 0,00 & 0,00 & 0,00 & 0,00 & 0,00 & 0,00 & 0,00 & 0,00 & 0,00 & 0,00 & 0,00 & 0,00 & 0,00 & 0,00 & 0,00 & 0,00 & 0,00 & 0,00 \\
\hline & 142 & 0,00 & 0,00 & 0,00 & 0,00 & 0,00 & 0,00 & 0,00 & 73,55 & 0,00 & 0,00 & 0,00 & 0,00 & 0,00 & 0,00 & 0,00 & 0,00 & 0,00 & 0,00 & 0,00 & 0,00 & 0,00 & 0,00 & 0,00 & 0,00 & 0,00 \\
\hline & 211 & 0,00 & 0,00 & 0,00 & 0,00 & 0,00 & 0,00 & 0,00 & 0,00 & 46,72 & 56,67 & 0,00 & 46,03 & 0,00 & 0,00 & 0,00 & 0,00 & 52,52 & 0,00 & 0,00 & 0,00 & 0,00 & 2,34 & 0,00 & 0,00 & 0,00 \\
\hline & 212 & 0,00 & 0,00 & 0,00 & 0,00 & 0,00 & 0,00 & 0,00 & 0,00 & 0,00 & 0,00 & 0,00 & 0,00 & 0,00 & 0,00 & 0,00 & 0,00 & 0,00 & 0,00 & 0,00 & 0,00 & 0,00 & 0,00 & 0,00 & 0,00 & 0,00 \\
\hline & 222 & 0,00 & 0,00 & 0,00 & 0,00 & 0,00 & 0,00 & 0,00 & 2,16 & 1,15 & 0,00 & 78,85 & 0,00 & 0,00 & 1,30 & 0,00 & 0,00 & 0,00 & 0,00 & 0,00 & 0,00 & 0,00 & 0,00 & 0,00 & 0,00 & 0,00 \\
\hline & 231 & 0,00 & 0,00 & 0,00 & 0,00 & 0,00 & 0,00 & 0,00 & 0,00 & 0,00 & 0,00 & 0,00 & 53,97 & 0,00 & 0,00 & 0,00 & 0,00 & 0,00 & 0,00 & 0,00 & 0,00 & 0,00 & 0,00 & 0,00 & 0,00 & 0,00 \\
\hline & 241 & 0,00 & 10,02 & 0,00 & 00,00 & 0,00 & 0,00 & 0,00 & 0,50 & 1,31 & 0,00 & 1,47 & 0,00 & 100,00 & 0,27 & 1,40 & 0,00 & 0,00 & 0,00 & 0,00 & 0,00 & 0,00 & 0,00 & 0,00 & 0,00 & 0,00 \\
\hline & 242 & 0,00 & 7,87 & 39,55 & 0,00 & 0,00 & 0,00 & 100,00 & 6,22 & 50,82 & 43,33 & 17,96 & 0,00 & 0,00 & 98,08 & 0,50 & 0,00 & 0,00 & 0,00 & 0,00 & 0,00 & 0,00 & 0,00 & 0,00 & 0,00 & 0,00 \\
\hline & 243 & 0,00 & 0,00 & 0,00 & 0,00 & 0,00 & 0,00 & 0,00 & 0,33 & 0,00 & 0,00 & 0,00 & 0,00 & 0,00 & 0,00 & 97,58 & 0,00 & 0,00 & 0,00 & 0,00 & 0,00 & 0,00 & 0,00 & 0,00 & 0,00 & 0,00 \\
\hline & 312 & 0,00 & 0,95 & 0,00 & 0,00 & 0,00 & 0,00 & 0,00 & 17,25 & 0,00 & 0,00 & 0,00 & 0,00 & 0,00 & 0,00 & 0,04 & 94,77 & 0,00 & 0,00 & 21,47 & 0,00 & 0,00 & 0,00 & 0,00 & 0,00 & 0,00 \\
\hline & 321 & 0,00 & 0,00 & 0,00 & 0,00 & 0,00 & 0,00 & 00 & 0,00 & 0,00 & 0,00 & 0,00 & 0,00 & 0,00 & 0,00 & 0,00 & 0,00 & 47,48 & 0,00 & 0,00 & 0,00 & 0,00 & 1,76 & 0,00 & 0,00 & 0,00 \\
\hline & 323 & 0,00 & 0,00 & 0,00 & 0,00 & 0,00 & 0,00 & $0,0 c$ & 0,00 & 0,00 & 0,00 & 0,00 & 0,00 & 0,00 & 0,35 & 0,48 & 0,00 & 0,00 & 100,00 & 0,00 & 0,00 & 0,00 & 0,00 & 0,00 & 0,00 & 0,00 \\
\hline & 324 & 0,00 & 0,00 & 0,00 & 0,00 & 0,00 & 0,00 & 0,00 & 0,00 & 0,00 & 0,00 & 1,73 & 0,00 & 0,00 & 0,00 & 0,00 & 5,23 & 0,00 & 0,00 & 78,53 & 0,00 & 0,00 & 0,00 & 0,00 & 0,00 & 0,00 \\
\hline & 331 & 0,00 & 0,00 & 0,00 & 0,00 & 0,00 & 0,00 & 0,00 & 0,00 & 0,00 & 0 & 0,00 & 0,00 & 0,00 & 0,00 & 0,00 & 0,00 & 0,00 & 0,00 & 0,00 & 94,78 & 0,04 & 0,00 & 0,00 & 1,63 & 0,00 \\
\hline & 421 & 0,00 & 0,00 & 0,00 & 0,00 & 0,00 & 0,99 & 0,00 & 0,00 & 0,00 & 0,00 & 0,00 & 0,00 & 0,00 & 0,00 & 0,00 & 0,00 & 0,00 & 0,00 & 0,00 & 0,00 & 99,63 & 1,29 & 0,00 & 0,00 & 0,00 \\
\hline & 422 & 0,00 & 0,00 & 0,00 & 0,00 & 0,00 & 2,48 & 0,00 & 0,00 & 0,00 & 0,00 & 0,00 & 0,00 & 0,00 & 0,00 & 0,00 & 0,00 & 0,00 & 0,00 & 0,00 & 0,00 & 0,00 & 94,61 & 0,00 & 0,00 & 0,00 \\
\hline & 512 & 0,00 & 0,00 & 0,00 & 0,00 & 0,00 & 0,00 & 0,0 & 0,00 & 0,00 & 0,00 & 0,00 & $0, c$ & 0,00 & 0,00 & 0,00 & 0,00 & 0,00 & 0,00 & 0,00 & 0,00 & 0,00 & 0,00 & 100,00 & 0,00 & 0,00 \\
\hline & 521 & 0,00 & 0,00 & 0,00 & 0,00 & 0,00 & 0,00 & 0,00 & 0,00 & 0,00 & 0,00 & 0,00 & 0,00 & 0,00 & 0,00 & 0,00 & 0,00 & 0,00 & 0,00 & 0,00 & 1,62 & 0,33 & 0,00 & 0,00 & 98,37 & 0,00 \\
\hline & 995 & 0,00 & 0, & 0,0 & & & 0, & & 0,00 & 0, & & 0, & & 0 & 0 , & & 0, & & 0 & & 3,60 & 0,00 & 0,00 & 0,00 & 0,00 & 100,00 \\
\hline & Total & 0,00 & 0,00 & 00,00 & 00,00 & 100,00 & 0,00 & 00,00 & 100,00 & 00,00 & 100,00 & 100,00 & 100,00 & 100,00 & 100,00 & 100,00 & 100,00 & 100,00 & 100,00 & 100,00 & 100,00 & 100,00 & 100,00 & 100,00 & 100,00 & 100,00 \\
\hline
\end{tabular}

\subsection{Landscape metrics in the study area}

\subsubsection{Landscape level}

Landscape level results are shown in table 2:

Table 2 - landscape-level results for study area

\begin{tabular}{|c|c|c|c|c|c|}
\hline YEAR & NP & AREA_MN & GYRATE_MN & CONTAG & SHDI \\
\hline 1990 & 223 & 197,41 & 490,02 & 55,14 & 2,23 \\
\hline 2000 & 242 & 181,91 & 473,14 & 55,38 & 2,30 \\
\hline
\end{tabular}

An evolution towards higher number of patches (NP) and smaller patches in average (AREA_MN) can be interpreted as a general trend to fragmentation. Results for GYRATE_MN are slightly smaller as well, which can be interpreted as less complex patch shapes (natural patches, e.g. forests or saltmarshes are usually more complex in shape; artificial patches, e.g. urban or industrial areas, are less complex).

\subsubsection{Class level}

In 20003 new LCT were detected: "122-Road and railroad networks and associated land" (associated to new access infrastructures from A-22 highway to Loulé), "133-Construction sites" (quarry), and "211-Permanently irrigated land" (irrigated area near Olhao). All these classes are represented by one single patch (NP) and developed on previously agriculture land (Table 3), although they occupy a very small part of the study area (PLAND).

Values for "111-CONT URBAN" remained constant in the analyzed period. Evolution of "112- DISC URBAN" is different, 
with a small increase in PLAND and NP, and with AREA_MN and GYRATE_MN also increasing, which can be interpreted as the insertion of new patches and the growth of the existing ones with an increase of their complexity, probably due to their development along linear infrastructures. The detected increase of "142-GOLF" in the contingency matrix (Table 1 ) is reflected in NP ( 2 to 4 ) and in PLAND (2,01 to 2,74\%), registering a decrease in AREA_MN and GYRATE_MN, which indicates the appearing of smaller, more compact patches (see also comments in section 3.1).

Table 3 - Class level results for the whole study area

\begin{tabular}{|c|c|c|c|c|c|}
\hline LAND COVER TYPES & YEAR & PLAND & NP & AREA_MN & GYR_MN \\
\hline \multirow{2}{*}{111 - Continuous urban fabric } & 1990 & 0,54 & 2 & 118,00 & 419,42 \\
\hline & 2000 & 0,54 & 2 & 118,00 & 419,42 \\
\hline \multirow{2}{*}{112 - Discontinuous urban fabric } & 1990 & 2,32 & 16 & 63,81 & 398,90 \\
\hline & 2000 & 2,86 & 17 & 74,00 & 402,60 \\
\hline \multirow{2}{*}{121 - Industrial or commercial units } & 1990 & 0,30 & 5 & 26,60 & 251,00 \\
\hline & 2000 & 0,50 & 5 & 44,00 & 348,01 \\
\hline \multirow{2}{*}{122 - Road and rail networks and associated land } & 1990 & - & - & - & - \\
\hline & 2000 & 0,17 & 1 & 73,00 & 588,91 \\
\hline \multirow{2}{*}{123 - Port areas } & 1990 & 0,07 & 1 & 30,00 & 215,99 \\
\hline & 2000 & 0,07 & 1 & 30,00 & 215,99 \\
\hline \multirow{2}{*}{124 - Airports } & 1990 & 0,44 & 1 & 195,00 & 658,48 \\
\hline & 2000 & 0,46 & 1 & 202,00 & 674,92 \\
\hline \multirow{2}{*}{133 - Construction sites } & 1990 & - & - & - & - \\
\hline & 2000 & 0,07 & 1 & 30,00 & 274,61 \\
\hline \multirow{2}{*}{142 - Sport and leisure facilities } & 1990 & 2,01 & 2 & 443,50 & 936,47 \\
\hline & 2000 & 2,74 & 4 & 301,50 & 598,56 \\
\hline \multirow{2}{*}{211 - Non-irrigated arable land } & 1990 & 1,08 & 6 & 79,33 & 381,55 \\
\hline & 2000 & 1,39 & 11 & 55,45 & 344,36 \\
\hline \multirow{2}{*}{211 - Permanently irrigated land } & 1990 & - & - & - & - \\
\hline & 2000 & 0,07 & 1 & 30,00 & 293,89 \\
\hline \multirow{2}{*}{222 - Fruit trees and berry plantations } & 1990 & 3,65 & 14 & 114,79 & 480,19 \\
\hline & 2000 & 4,34 & 16 & 119,38 & 462,30 \\
\hline \multirow{2}{*}{231 - Pastures } & 1990 & 0,08 & 1 & 34,00 & 267,15 \\
\hline & 2000 & 0,14 & 1 & 63,00 & 330,66 \\
\hline \multirow{2}{*}{241 - Annual crops associated with permanent crops } & 1990 & 31,63 & 14 & 994,71 & 794,02 \\
\hline & 2000 & 30,90 & 15 & 906,93 & 746,81 \\
\hline \multirow{2}{*}{242 - Complex cultivation patterns } & 1990 & 13,84 & 15 & 406,13 & 743,78 \\
\hline & 2000 & 11,84 & 21 & 248,14 & 595,77 \\
\hline \multirow{2}{*}{$\begin{array}{l}243 \text { - Land principally occupied by agriculture with significant } \\
\text { areas of natural vegetation }\end{array}$} & 1990 & 10,62 & 39 & 119,85 & 431,38 \\
\hline & 2000 & 10,87 & 38 & 125,95 & 442,89 \\
\hline \multirow{2}{*}{312 - Coniferous forest } & 1990 & 2,81 & 10 & 123,80 & 477,82 \\
\hline & 2000 & 2,34 & 8 & 129,00 & 469,38 \\
\hline \multirow{2}{*}{321 - Natural grasslands } & 1990 & 0,29 & 3 & 42,67 & 344,73 \\
\hline & 2000 & 0,54 & 4 & 59,50 & 386,40 \\
\hline \multirow{2}{*}{323 - Sclerophyllous vegetation } & 1990 & 8,36 & 31 & 118,68 & 478,30 \\
\hline & 2000 & 8,26 & 32 & 113,69 & 464,80 \\
\hline \multirow{2}{*}{324 - Transitional woodland-shrub } & 1990 & 0,51 & 3 & 75,33 & 410,30 \\
\hline & 2000 & 0,40 & 2 & 88,50 & 392,00 \\
\hline \multirow{2}{*}{331 - Beaches-dunes-sands } & 1990 & 2,45 & 8 & 135,00 & 822,60 \\
\hline & 2000 & 2,52 & 8 & 138,88 & 843,42 \\
\hline \multirow{2}{*}{421 - Salt marshes } & 1990 & 12,90 & 3 & 1892,67 & 1876,99 \\
\hline & 2000 & 12,92 & 3 & 1895,33 & 1877,85 \\
\hline 422 - Salines & 1990 & 1,84 & 8 & 101,50 & 491,62 \\
\hline 4L2-Salines & 2000 & 1,94 & 8 & 106,63 & 503,30 \\
\hline & 1990 & 0,05 & 1 & 23,00 & 255,98 \\
\hline S1L - vater boales & 2000 & 0,05 & 1 & 23,00 & 255,98 \\
\hline & 1990 & 3,52 & 3 & 516,00 & 1930,91 \\
\hline 521 - Coastal lagoons & 2000 & 3,49 & 4 & 384,00 & 1480,93 \\
\hline 995 - Unclassified water hodies & 1990 & 0,68 & 37 & 8,08 & 151,62 \\
\hline y9s - Uncrassilled water noules & 2000 & 0,59 & 37 & 7,00 & 135,97 \\
\hline
\end{tabular}

For the following results we opted to reduce the universe of analysis of 25 LCT by selecting a subset of LCT based on three criteria: 1 ) percentage of change above $6 \%$ (In Table 1, LCT in the diagonal between 94 and $100 \%$ ), disregarding LCT that showed no relevant change between 1990 and 2000; 2) total relative cover in the study area (PLAND) above $8 \%$ (Table 3 ) - 5 LCT $(241,242,243,323$, and 421$)$ together cover more than $3 / 4$ of the entire study area (77\%); 3) we did not disregard some LCT 
of artificial areas $(112,121,142)$ since they were of special interest for analyzing urban-tourism dynamics and associated activities. We obtained a subset of $12 \mathrm{LCT}$, thus reducing by more than half the original set. However, we do so by covering $94 \%$ of the observed change and $77 \%$ of the study area, thus analyzing the potentially more relevant data.

\subsection{Landscape metrics in homogeneous areas}

\subsubsection{Landscape level}

Following the analysis shown for the whole landscape we analyzed the homogeneous areas, first at the landscape level (Table 4):

Table 4 - Results for homogeneous areas at landscape level

\begin{tabular}{|c|c|c|c|c|c|c|}
\hline YEAR & NP & AREA_MN & GYRATE_MN & CONTAG & SHDI \\
\hline 1990 & 143 & 161,47 & 399,36 & 62,19 & 1,69 \\
\hline 2000 & 189 & 122,35 & 329,21 & 62,51 & 1,77 \\
\hline
\end{tabular}

The decrease in AREA_MN between 1990 and 2000 is sharper than for the whole landscape, and the increase in NP is bigger. GYRATE_MN presents lower values, and its decrease is remarkable, showing a trend towards patch compacity in this period. SHDI shows a slight increase, probably due to the three new classes appearing in the area, as well as the re-distribution of patches from other classes. "242-COMPLEX MOSAIC" was the LCT that was mostly substituted by periurban development around Faro and Olhão: "112-DISC URB" grew c. 8 \% over this class, as did "121-IND COM" (c.40\%) and "142- GOLF" (c.6\%), among others. The latter also "robbed" 17\% from "312-CONIF" (Table 1).

\subsubsection{Class level}

Class level analysis in homogeneous areas will allow us to know the explanatory factors of homogeneity in the landscape (Table 5). Thus, it can be seen that $80 \%$ of the area is represented by only 4 LCT: "241-TRAD ORCHARDS" (44\%), "421-Salt marshes" (14\%), "243-AGRIC SIGN NAT VEGETATION" (12\%) and "323-SHRUB" (11\%). Consequently, homogeneity is explained by 2 groups of LCT: those linked to marine environments (salt marshes) and those linked to agricultural areas located mainly in the north and east of the study area. The CT (Table 1) shows a high stability for the latter in the 1990-2000 period. Nevertheless, metrics allowed to detect important modifications for "242-COMPLEX MOSAIC": increase in NP (13 to 25 ) and decrease in PLAND (11 to $7 \%$ ), in AREA_MN (206 to 64 ha), and in GYRATE_MN (418 to 248), all of these pointing to a strong fragmentation of this LCT.

Table 5 - Class level results for metrics in homogeneous areas

\begin{tabular}{|c|c|c|c|c|c|}
\hline LAND COVER TYPES & YEAR & PLAND & NP & AREA_MN & GYR_MN \\
\hline \multirow{2}{*}{112 - Discontinuous urban fabric } & 1990 & 0,38 & 6 & 14,50 & 144,01 \\
\hline & 2000 & 0,19 & 7 & 6,43 & 102,77 \\
\hline \multirow{2}{*}{142 - Sport and leisure facilities } & 1990 & 0,32 & 1 & 73,00 & 334,95 \\
\hline & 2000 & 1,40 & 3 & 107,67 & 279,81 \\
\hline \multirow{2}{*}{211 - Non-irrigated arable land } & 1990 & 0,19 & 1 & 43,00 & 266,45 \\
\hline & 2000 & 0,78 & 8 & 22,63 & 183,83 \\
\hline \multirow{2}{*}{241 - Annual crops associated with permanent crops } & 1990 & 43,70 & 21 & 480,48 & 689,85 \\
\hline & 2000 & 43,92 & 24 & 423,21 & 531,86 \\
\hline \multirow{2}{*}{242 - Complex cultivation patterns } & 1990 & 11,57 & 13 & 205,54 & 418,26 \\
\hline & 2000 & 6,91 & 25 & 63,88 & 247,88 \\
\hline \multirow{2}{*}{$\begin{array}{l}243 \text { - Land principally occupied by agricult. w/ significant } \\
\text { areas of natural vegetation }\end{array}$} & 1990 & 12,07 & 29 & 96,07 & 336,65 \\
\hline & 2000 & 12,40 & 29 & 98,90 & 359,28 \\
\hline \multirow{2}{*}{312 - Coniferous forest } & 1990 & 0,02 & 1 & 5,00 & 84,93 \\
\hline & 2000 & 0,47 & 2 & 54,00 & 258,54 \\
\hline \multirow{2}{*}{321 - Natural grasslands } & 1990 & 0,03 & 1 & 7,00 & 138,49 \\
\hline & 2000 & 0,06 & 3 & 4,33 & 83,60 \\
\hline \multirow{2}{*}{323 - Sclerophyllous vegetation } & 1990 & 11,24 & 33 & 78,64 & 377,45 \\
\hline & 2000 & 11,56 & 32 & 83,53 & 398,44 \\
\hline \multirow{2}{*}{421 - Salt marshes } & 1990 & 13,88 & 5 & 641,20 & 914,99 \\
\hline & 2000 & 14,51 & 5 & 671,00 & 933,36 \\
\hline
\end{tabular}

\subsection{Landscape metrics in heterogeneous areas}

\subsubsection{Landscape level}

In heterogeneous areas (Table 6), the general trends are similar to the former cases: decrease in AREA_MN, increase in NP. However, absolute values for the mean patch area are far lower, and number of patches higher, confirming the heterogeneity. In addition, GYRATE_MN registers an exaggerated increase, probably because the truncating effect imposed by the limits of the heterogeneous areas, producing long patches with more complex shapes. 
Table 6 - Landscape level results for metrics in heterogeneous areas

\begin{tabular}{|c|c|c|c|c|c|c|}
\hline YEAR & NP & AREA_MN & GYRATE_MN & CONTAG & SHDI \\
\hline 1990 & 271 & 77,24 & 372,83 & 47,05 & 2,56 \\
\hline 2000 & 289 & 72,31 & 912,31 & 48,16 & 2,60 \\
\hline
\end{tabular}

For the same reason, the total number of patches in the landscape doesn't coincide with the sum of the patches in homogeneous and heterogeneous zones, as the divided patches are counted on both areas.

\subsubsection{Class level}

Class level analysis allowed identifying the causes for heterogeneity; $80 \%$ of heterogeneous areas are covered by 11
LCT, almost three-fold as compared with homogenous areas (Table 7). In addition, they present a series of LCT which are absent in homogeneous areas, e.g. "121-INDUSTRY", "212IRRIGATED" or "231-Pastures". The presence of a higher number of classes is one of the main factors for heterogeneity.

Note that the LCT "241-TRAD ORCHARDS" that dominates homogeneous areas (i.e. the landscape matrix with the highest PLAND of $44 \%$, see Table 5) - covers less than half (17\%) of heterogeneous areas in 2000. On the other hand, NP is much higher (44 versus 24 ), and consequently, AREA_MN is lower (78 versus 423 ha). GYRATE_MN reveals much less complex (more artificial landscape pattern) shapes in heterogeneous areas $(352 \mathrm{~m})$ than in the homogeneous $(532 \mathrm{~m})$. A similar trend can be seen in LCT responsible for homogeneity, e.g. "421- Salt marshes".

Table 7 - Class level results for heterogeneous areas

\begin{tabular}{|c|c|c|c|c|c|}
\hline LAND COVER TYPES & YEAR & PLAND & NP & AREA_MN & GYR_MN \\
\hline \multirow{2}{*}{112 - Discontinuous urban fabric } & 1990 & 4,46 & 15 & 62,27 & 391,15 \\
\hline & 2000 & 5,80 & 18 & 67,39 & 377,97 \\
\hline \multirow{2}{*}{121 - Industrial or commercial units } & 1990 & 0,64 & 5 & 26,60 & 251,00 \\
\hline & 2000 & 1,05 & 5 & 44,00 & 348,01 \\
\hline \multirow{2}{*}{142 - Sport and leisure facilities } & 1990 & 3,89 & 2 & 407,00 & 972,54 \\
\hline & 2000 & 4,23 & 6 & 147,17 & 506,07 \\
\hline \multirow{2}{*}{211 - Non-irrigated arable land } & 1990 & 2,07 & 6 & 72,17 & 367,99 \\
\hline & 2000 & 2,05 & 10 & 42,90 & 299,54 \\
\hline \multirow{2}{*}{212 - Permanently irrigated land } & 1990 & - & - & - & - \\
\hline & 2000 & 0,14 & 1 & 30,00 & 293,89 \\
\hline \multirow{2}{*}{231 - Pastures } & 1990 & 0,16 & 1 & 34,00 & 267,15 \\
\hline & 2000 & 0,30 & 1 & 63,00 & 330,66 \\
\hline \multirow{2}{*}{241 - Annual crops associated with permanent crops } & 1990 & 18,33 & 46 & 83,39 & 370,67 \\
\hline & 2000 & 16,49 & 44 & 78,34 & 351,55 \\
\hline \multirow{2}{*}{242 - Complex cultivation patterns } & 1990 & 16,34 & 20 & 171,00 & 626,21 \\
\hline & 2000 & 17,29 & 23 & 157,13 & 560,30 \\
\hline \multirow{2}{*}{$\begin{array}{l}243 \text { - Land principally occupied by agriculture. w/ } \\
\text { significant areas of natural vegetation }\end{array}$} & 1990 & 9,02 & 37 & 51,03 & 280,33 \\
\hline & 2000 & 9,18 & 35 & 54,80 & 284,36 \\
\hline \multirow{2}{*}{312 - Coniferous forest } & 1990 & 5,89 & 11 & 112,09 & 429,46 \\
\hline & 2000 & 4,42 & 10 & 92,40 & 396,88 \\
\hline \multirow{2}{*}{321 - Natural grasslands } & 1990 & 0,58 & 3 & 40,33 & 325,95 \\
\hline & 2000 & 1,08 & 5 & 45,00 & 301,49 \\
\hline \multirow{2}{*}{323 - Sclerophyllous vegetation } & 1990 & 5,18 & 20 & 54,20 & 286,83 \\
\hline & 2000 & 4,62 & 19 & 50,79 & 259,49 \\
\hline \multirow{2}{*}{421 - Salt marshes } & 1990 & 11,81 & 16 & 154,50 & 544,27 \\
\hline & 2000 & 11,15 & 15 & 155,40 & 589,11 \\
\hline
\end{tabular}

\section{Discussion}

\subsection{Urban transformation dynamics}

Based on the results we detected three main types of urban development. The first is constituted by development around consolidated urban fabric, following an expansive dynamic which can adopt the form of residential (NW of Faro), or industrial ( $\mathrm{S}$ of Loulé) areas. This growth was established mainly on suburban agricultural areas, namely over "241-TRAD ORCHARDS" (10\%) and "242-COMPLEX MOSAIC" (8\%) (Table 1) along with an increase of "112-DISC URBAN". NP doesn't grow but patches area grew bigger in average from 64 to 74 ha. "121INDUSTRIAL", a minority in the study area (PLAND $=0,30 \%$ in 1990) also showed this kind of growth, always developing on lands formerly occupied by "242-COMPLEX MOSAIC". It develops from consolidated areas (NP doesn't change and AREA_MN increases). From QuickBird sensor images and field work we could detect also in the last years a linear trend surrounding communication networks, as manifested in rising GYRATE_MN values (from 251 to $348 \mathrm{~m}$ ). Summing up, there is a growth in previously existing patches under Artificial Areas (LCT 111, 112, 121, 122, 123 and 132), namely the cities of Faro 
and Olhão, as well as along the transportation network, namely A-22 and EN-125, and the railroad.

A second type is constituted by urban growth associated with golf courses. The development strategy, common in the area, differs from the former since it is not based in the expansion of the existent urban fabric: along with the construction of golf courses, residential dwellings are built around and along the fairways, resulting in low density urbanization such as in the resorts Vale de Lobo and Quinta do Lago SW of Faro. Landscape metrics allowed detecting a growth for class "142-GOLF", NP increasing, and a sharp drop in AREA_MN, which means it is spreading in smaller patches. This growth is possible mainly over pine woods ("312-CONIF"), which show a slight decrease in PLAND and NP, slightly increasing AREA_MN, which means they are disappearing. Considering it altogether, it can be interpreted as "shrinkage" (golf course spreading) and "attrition" (disappearance of pine woods) spatial processes of transformation.

The third kind of urban growth is represented by the discontinuous, non-planned expansion of urban areas from the road network into the "hinterland", mainly over "241-TRAD ORCHARDS". This type of growth cannot be detected by analysis of CLC data, as occur in parcels far smaller than the MMU of the maps. It was detected in visual analysis of high-resolution images and field work. This kind of growth is characteristic for this LCT, i.e. it could be observed in all patches belonging to this class.

\subsection{Spatial distribution of heterogeneity}

Differentiation between areas with different heterogeneity allowed defining clear differences in the study area (Figure 4). Heterogeneous areas correspond to the coastal landscape, following the main road infrastructures (A-22, EN-125), and into areas more flat. Homogeneous areas are clearly divided between Ria Formosa marshes and lagoons (down south) and inland hilly areas (up North, into the "Barrocal").

Landscape metrics calculated in both homogeneous and heterogeneous areas allowed to distinguish them based on the differences on composition and configuration of landscape elements (patches).

At the landscape level, patches are more abundant and smaller in heterogeneous areas than in homogeneous area (NP 289 versus 189; AREA_MN 72 ha versus 122). Thus coastal landscapes are more fragmented than inland ("Barrocal") which LCT are more aggregated and complex. Indeed, CONTAG has higher values in the homogeneous area (63 versus 48 ), which can be interpreted as a higher aggregation in patches in this area. GYRATE_MN is lower $(329 \mathrm{~m})$ than in the heterogeneous one $(912 \mathrm{~m})$, indicating a higher complexity in configuration of patches for the latter. Finally, as expected, SHDI is lower in homogeneous area (2) than in the heterogeneous (3).

Class level metric results allow knowing details about landscape composition in each case. $80 \%$ of land cover in the homogeneous zone is due to 4 LCT and in heterogeneous to 11 . In the homogeneous area, $43 \%$ of land cover is occupied by
"241-TRAD ORCHARDS", the matrix in this sub-area - the most frequent land cover /use (Forman, 1995). The high share of the other two terrestrial classes (15\% are "421- Salt marshes"), namely "243-AGRIC SIGN NAT VEGETATION" (12\%) and "323SHRUB" (12\%), characterize homogeneous areas as lowdynamic in terms of land use, due to the important natural component on both classes. Indeed, land covers associated to more dynamic and intensified agriculture have minor contributions, e.g. "222- Fruit trees and berry plantations" (3\%) or "211-NON IRRIGATED" (1\%).

In heterogeneous areas, one of the LCT with high relative occupation is "242-COMPLEX MOSAIC" (17\%). As previously exposed, it represents a mosaic of land uses with different dynamics, and which tends to evolve by replacing extensive, more traditional land uses by more intensive. The other LCT is "241-TRAD ORCHARDS" (17\%), which we believe it was also the matrix here. However, due to the proximity of the coast and thus to larger urban areas and tourism activities, it has been replaced gradually by other LCT, first by a mix of old and new land uses - the "242-COMPLEX MOSAIC", and later this is substituted by artificial uses such urban areas (continuous or discontinuous), industrial, roads, construction sites, golf courses, etc.

Urban habitat is important with "112-DISC URBAN" and "142GOLF" summing up $10 \%$. Due to the proximity of the ocean, marine environments are also well represented by LCT such as "421-Salt marshes" (11\%). In synthesis heterogeneous areas are characterized by very different LCT, which can be associated with different land use dynamics, thus being more prone to develop land use conflicts, and to landscape degradation.

\subsection{Scale effects}

Field work together with visual inspection of high-resolution remote-sensed images allowed identifying effects which are not sufficiently represented in CLC maps. Relevant to the discussion on urbanization and tourism is the scattered urban development along the main road network. It consists in the invasion of former agricultural areas by the chaotic and non-planned construction of buildings in little parcels. This process follows a progression from the axis marked by the main transport network, extending progressively towards the interior of agricultural areas following secondary and tertiary roads.

This urban dynamic is initiated by small areas of expanding LCT, with patch sizes lower than the MMU and/or resolution of the CLC cartography. To solve this issue later we conducted similar studies, for the entire region of Algarve, with a focus on coastal areas that combined CLC $(1990,2000$, and 2006) and COS (1990 and 2007). These studies allowed us to detect urban sprawl in a dispersed pattern (Aguilera \& Botequilha-Leitão, 2012; Aguilera et al., 2014). In the future we need to deepen these studies for the presented study area - the FLOS, and to use CLC 2012 to further validate our assumptions and results. 


\section{Conclusions}

The Algarve region faces emergent challenges posed by European, national and regional guidelines for spatial planning. Directly related with these issues is the future role of coastal tourism landscapes affected by urban sprawl. In the last four decades' sprawl is growing and spreading over time, and it is impacting local resources and the coastal landscapes, e.g. around the city of Faro and the tourism resorts nearby such as Quinta do Lago and Vale do Lobo. If the underlying processes are not counteracted they will continue to degrade this landscape, and thus gradually losing their productive and cultural functions, potentially affecting tourism and urban quality of life for the resident and visiting populations. We have presented a casestudy in Faro and its surrounding towns and resorts.

CLC data has revealed a great utility due to its easy availability, and to the fact of being a source of information adopted by a large group of European countries. In this manner, similar studies developed in other countries can be directly comparable to the results presented hereby. Nevertheless, even when the analysis allowed to detect and describe important trends in the use of land in the area, the previous detailed analysis of land use classes was essential to interpret the results of the metrics. Thus, we consider essential for further developments of this research to perform analysis with higher resolution data, in order to enhance the understanding, in quantitative terms, of processes like the expansion of urbanization over agricultural land, and the intensification of some agricultural land uses. Indeed, the resolution of the CLC data did not allowed quantifying the dispersed type of urban sprawl that was detected, by use of Google-Earth tools and field work, in the "Barrocal" part of our study area.

The utility of spatial metrics was based on several factors: first, the choice of a fixed spatial reference to compare two different time periods; thus the selection of a series of metrics that could be easily combined as to derive results with a straightforward interpretation. Processes such as fragmentation, shrinkage, or attrition, or the development of new areas were easily detected in the metrics results, using solely two time steps. In addition, the technique of moving windows used for the calculation of some metrics allowed transforming discrete results in continuous spatial information, thus facilitating the task of identifying gradients of landscape heterogeneity.

Our results suggest an important degree of intensification of land uses in the coast, contrasting with a more stable interior zone. The more intensified area faces possible actual and future conflicts regarding peri-urban development in regards with agricultural uses, facing mainly two distinct processes, both non-planned: invasion of agricultural areas by chaotic urban development and the destruction of pine forests over coastal sandy soils both associated with tourism development. The spatial manifestation of these processes involves the fragmentation and/or reduction of high ecological and landscape cultural value.
Key challenges for a sustainable tourism policy (Izzo 2010) in the Algarve are: (1) reducing the seasonality of demand (one of the weaknesses and threats for tourism in the Algarve), (2) counteracting the spatial concentration of tourists on the coast (another serious problem in this region), (3) preserving and giving value to natural and cultural heritage (abundant also in inland landscapes), promoting territorial cohesion and maintaining and enhancing community prosperity and quality of life, in the face of global change.

Land use planning must pay more attention to tourism, and adopt combined spatial approaches, and monitor quality indicators to evaluate initiatives, learn with past results, and do better plans (adaptive approach to planning). Metrics are good landscape indicators to that purpose. According to Butler (2011) tourism has changed more in the last three decades than at almost any other comparable time period. The Algarve region competes directly with other Mediterranean regions based on its traditional product. Presently it is profiting from insecurity in some Eastern Mediterranean countries due to political turmoil and warfare. But this will change in the future. Algarve must take this opportunity to use its base model as a leverage to develop and consolidate other products that run all year and take advantage from the beautiful and large natural areas located more in the interior.

There is a need for planning instruments that helps identifying shared interests, building common strategies, and build consensus on the role that alternative tourism based on our natural and rural landscapes in the interior will play in the future of this region. We believe that a hybrid method combining spatial and strategic planning (collaborative, prospective, adaptive) can play this role by mediating the several interests working separately within each institution, private owners, resorts, municipalities, towns or cities involved, and provide planning tools to allow us to better envision a smarter future.

The undergoing revision of most of the (first generation of) Municipal Plans (PDM) creates an opportunity to adopt new planning methods, to find new strategies and to preserve this landscape by promoting a new set of landscape functions that serve a new, to be formed coastal space looked under the emergent paradigms of sustainable tourism, proof-climate resilient cities, and green infrastructures.

\section{References}

Aguilera, F. \& Botequilha-Leitão, A. (2012). Selección de métricas de la ecología del paisaje mediante ACP para la caracterización de los procesos de alteración del paisaje del Algarve (Portugal). International Review of Geographical Information Science and Technology, 12, 93-121.

Aguilera, F., Valenzuela-Montes, L.M. \& Botequilha-Leitão, A. (2011). Landscape metrics in the analysis of urban land use patterns: A case study in a Spanish metropolitan area. Landscape and Urban Planning, 99, 226-238.

Aguilera, F., Botequilha-Leitão, A. \& Diáz-Varela, E. (2014). Detecting multi-scale urban growth patterns and processes in the Algarve Region (Southern Portugal). Applied Geography, 53, 234-245. 
Almeida, R. C., Ferreira, A.M \& Costa, C. (2011). Turismo residencial e resorts integrados. Estratégias de rejuvenescimento em destinos maduros? O Caso do Algarve. In M. Sarmento \& A. Matias (eds.), Economics and Management of Tourism. Trends and Recent Developments (pp.173-196). Lisboa: Universidade Lusíada.

Botequilha-Leitão, A. (2001). Sustainable Land Planning. Towards a planning framework. Exploring the role of spatial statistics as a planning tool. Doctoral dissertation. Instituto Superior Técnico. Lisboa: Universidade Técnica de Lisboa.

Botequilha-Leitão, A. (2009). Land Use Planning in Portugal: Brief history and emergent challenges. The case of peri-urban landscape of Faro (Algarve Region, Portugal). T. Panagopoulos (ed.), New Models for Innovative Management and Urban Dynamics (pp.23-40). Faro: COST, European Science Fondation and Universidade do Algarve.

Botequilha Leitão, A. \& Ahern, J. (2002). Applying Landscape Ecological Concepts and Metrics in Sustainable Landscape Planning. Landscape and Urban Planning, 59, 65-93.

Botequilha Leitão, A., Miller, J., Ahern, J. \& McGarigal, K. (2006). Measuring landscapes. A Planner's Handbook. Washington DC: Island Press.

Brown G. (2006). Mapping Landscape Values and Development Preferences: a Method for Tourism and Residential Development Planning. Int. J. Tourism Res., 8, 101-113.

Butler, R. (2011). Tourism Area Life Cycle. Contemporary Tourism Reviews. Oxford: Goodfellow Publishers Limited.

Calvo-Iglesias, M.S., Fra-Paleo, U., Crecente-Maseda, R. \& Díaz-Varela, R.A. (2006). Directions of change in land cover and landscape patterns from 1957 to 2000 in agricultural landscapes in NW Spain. Environmental Management, 38, 921-933.

Caetano, M., Carrão, H. \& Painho, M. (2005). Alterações da ocupação do solo em Portugal Continental (Land use changes in Continental Portugal): 1985-2000. Lisboa: Instituto do Ambiente.

CCDR Algarve (2007). Plano Regional de Ordenamento do Território do Algarve (PROTAL). Proposta de Plano. Faro: Comissão de Coordenação e Desenvolvimento Regional do Algarve.

CCDR Algarve (2004). Plano Regional de Ordenamento do Território do Algarve. Vol. II - Caracterização e Diagnóstico. Parte 2. Anexo NDinâmicas Demográficas. Comissão de Coordenação e Desenvolvimento Regional do Algarve. Faro: Comissão de Coordenação e Desenvolvimento Regional do Algarve.

CCR Algarve (2002). Estudo de Avaliação do PROTAL (1989/1996). Plano Regional de Ordenamento do Território do Algarve. Vol. II - Relatório de Caracterização e Diagnóstico. Parte 1. Faro: Comissão de Coordenação Regional do Algarve.

Diaz-Varela, E.R., Álvarez-López, C.J. \& Marey-Pérez, M.F. (2009). Multiscale delineation of landscape planning units based on spatial variation of land-use patterns in Galicia, NW Spain. Landscape and Ecological Engineering, 5, 1-10.

DiBari, J. (2007). Evaluation of five landscape-level metrics for measuring the effects of urbanization on landscape structure: the case of Tucson, Arizona, USA. Landscape and Urban Planning, 79, 308-313.

Dodds, R. \& Butler, R. (2010). Barriers to implementing sustainable tourism policy in mass tourism destinations. Tourismos: $A n$ international Multidisplinary Journal of Tourism, 5 (1), 35-53.

Earth Resources Observation and Science Center (EROSC) (2007). Shuttle Radar Topography Mission (SRTM). United States Geological Survey. Retrieved April 27 ${ }^{\text {th }}, 2009$ from http://eros.usgs.gov/products/elevation/srtmbil.php

EEA (2007). Corine land cover. Retrieved May $12^{\text {th }}, 2009$ from http://www.eea.europa.eu/data-and-maps/

Forman, R.T.T. (1995). Land mosaics: The ecology of landscapes and regions. Cambridge: Cambridge University Press.

Freire, S. \& Caetano, M. (2005). Assessment of land cover change in Portugal from 1985 to 2000 using landscape metrics and GIS. Proceedings of the Conference GISPLANET'05. June 2, Estoril.
Gustafson, E.J. (1998). Quantifying Landscape Spatial Pattern: What Is the State of the Art? Ecosystems, 1, 143-156.

Gkoltsiou, A. \& Terkenli, T.S. (2012). An interdisciplinary analysis of tourist landscape structure. Tourismos: An International Multidisciplinary Journal of Tourism, 7, 145-164.

Herold, M., Goldstein, N. \& Clarke, K. (2003). The spatio-temporal form of urban growth: measurement, analysis and modeling. Remote Sensing of Environment, 85, 95-105.

Herold, M., Couclelis, H. \& Clarke K.C. (2005). The role of spatial metrics in the analysis and modelling of urban land use change. Comput Environ Urban, 29, 369-399.

Hildenbrand Scheid, A. (2008). El Espazo Transfronterizo AlgarveAndaluzia-Alentejo: El Reto de un Desarrollo Coherente. "Ciclo de Seminários em Ordenamento do Território" ("Seminars in Landuse Planning"), CEPTU, FERN. December, 15. Green Auditorium. Faro: University of Algarve.

INE (2011). XV Recenseamento Geral da População e V Recenseamento Geral da Habitação. Lisboa: Instituto Nacional de Estatística (INE).

Izzo, V. (2010). The importance of landscapes for tourism - the impact of tourism on landscapes. "Seminar on Landscape and Tourism". Directorate General for Enterprise and Industry. Gothenburg: European Comission.

Luck, M. \& Wu, J. (2002). A gradient analysis of the landscape pattern of urbanization in the Phoenix metropolitan area of USA. Landscape Ecology, 17, 327-339.

McGarigal, K., Cushman, S. A. Neel, M. C. \& Ene, E. (2002). FRAGSTATS: Spatial Pattern Analysis Program for Categorical Maps. Computer software program produced by the authors at the University of Massachusetts, Amherst. Retrieved January $17^{\text {th }}, 2003$ from http://www.umass.edu/landeco/research/fragstats/fragstats.html

O'Neill, R.V., Krummel, J. R., Gardner, R. H., Sugihara, G., Jackson, B., DeAngelis, D. L., Milne, B. T., Turner, M. G., Zygmunt, B., Christensen, S. W., Dale, V. H., Graham, R. L. (1988). Indices of landscape pattern. Landscape Ecology, 1(3): 153-162.

Petrov, L., Lavalle, C. \& Kasanko, M. (2009). Urban land use scenarios for a tourist region in Europe: Applying the MOLAND model to Algarve, Portugal. Landscape and Urban Planning, 92, 10-23.

Pham D.U. \& Nakagoshi N. (2007). Analyzing urban green space pattern and eco-network in Hanoi, Vietnam. Landscape and Ecological Engineering, 3, 143-157.

Poelmans, L. \& Van Rompaey, A. (2009). Detecting and modelling spatial patterns of urban sprawl in highly fragmented areas: A case study in the Flanders-Brussels region. Landscape and Urban Planning, 93, 10-19.

Ramos, J.S. (2010). Ciudad, Espacio Libre y Funcionalidad Ecologica. Una Aproximacion Territorial al Estudio del Medio Ambiente en el Area Metropolitana de Sevilla (City, Open Space and Ecological funcionality. A territorial approach to an environmental study of the Metropolitan Area of Seville, Spain). Doctoral thesis. Sevilha, Spain: Universidade Pablo de Olavide.

Riitters K.H., O'Neill R.V. \& Jones K.B. (1997). Assessing habitat suitability at multiple scales: a landscape-level approach. Biological Conservation, 81, 191-202.

Roshier D.A., Robertson A.I., Kingsford R.T. \& Green D.G. (2001). Continental-scale interactions with temporary resources may explain the paradox of large populations of desert waterbirds in Australia. Landscape Ecology, 16, 547-556.

Rutty, M. \& Scott, D. (2016). Comparison of Climate Preferences for Domestic and International Beach Holidays: A Case Study of Canadian Travelers. Atmosphere, 7, 30

Seto, K.C. \& Fragkias, M. (2005). Quantifying spatiotemporal patterns of urban land-use change in four cities of China with time series landscape metrics. Landscape Ecology, 20, 871-888.

Taubenbock, H., Wegmann, M., Roth, A., Mehl, H. \& Dech, S. (2009). Urbanization in India - Spatiotemporal analysis using remote sensing data. Computers, Environment and Urban Systems, 33, 179-188. 
Vaz, E. de Noronha, Nijkamp, P., Paínho, M. \& Caetano, M. (2012). A multi-scenario forecast of urban change: A study on urban growth in the Algarve. Landscape and Urban Planning, 104, 201- 211.

White, V., McCrum, G., Blackstock, K.L. \& Scott, A. (2006). Indicators of sustainability and sustainable tourism: Literature review and some example sets. Aberdeen: The Macaulay Institute.

Received: 27 February 2017

Revisions required: 15 June 2017

Accepted: 12 September 2017 